\title{
EKOSPIRITUALITAS YANG HOLISTIK
}

\author{
Weldemina Yudit Tiwery
}

\begin{abstract}
Ecology problems have been spread and affected to various aspects of humanity life. It is not rare to be found the ecology problems, and the impacts have hit us very seriously. The negative effects of the ecological destruction have been threatening the existence of human being as main actors who responsible to the problems which caused by their actions. The expolitation of nature, such as uncontroled mining, deforestation, and ilegal fishing by bombing; the crisis of cleaning water; scatered garbage, and others problems were only a few of problems which happened in our environment, and also the exploitation of certain region for partial political interest had been more complicated. The ecology crisises might be caused by nature itself, but in fact most of the problems had been caused by human actions. In evidence, at a place where inhabited by people, there never free from the heppening of various ecology crisises as worts impact of cosumerism of human being. People exploited the earth resources uncontroled, excesive, and unregulated. Nature has been considered as an object which could be exploited to fulfill their passion of cosumerism. Of course, here people have been denying their status-quo as co-worker or partner of God in managing and using this universe for their needs. The cosumemerism has been a habit to fulfill their excesive desire, massive exploitation, and of course, it contains of principle pleasure. Therefore, it should become a common concern, and also, it has to be a collective consciousness to figure out the problems.
\end{abstract}

Keywords : eco-spirituality, ecology, exploitation, crisis, existence, consumerism.

\begin{abstract}
Abstrak
Persoalan ekologi merupakan sesuatu yang telah mewabah dan memengaruhi beragam sendi kehidupan manusia. Tak jarang ditemui masalah-masalah seputar kehidupan ekologi itu, dampaknya pun tak tanggung-tanggung datang menerpa. Efek negatif dari perusakan alam ciptaan itu menggugat eksistensi manusia sebagai orang yang bertanggungjawab atas persoalan-persoalan yang timbul akibat dari perbuatannya. Eksploitasi terhadap alam, semisal pertambangan liar, penebangan hutan, dan pengeboman ikan; krisis air bersih; sampah yang bertebaran secara serampangan, juga beragam permasalahan lainnya merupakan segelintir persoalan yang marak terjadi di wilayah kita, belum lagi eksploitasi tempat-tempat tertentu untuk kepentingan politisparsial. Krisis ekologi bisa terjadi karena faktor alam, namun kebanyakan krisis itu justru disebabkan oleh perbuatan manusia. Ternyata di daerah di mana manusia tempati, tak pernah luput dari terjadinya berbagai macam krisis ekologis sebagai dampak buruk dari konsumerisme manusia. Manusia menyerap sumber-sumber daya bumi tanpa terkendali, berlebihan, dan tak teratur. Alam dianggap sebagai obyek yang dapat dimanfaatkan untuk
\end{abstract}


memenuhi hasrat konsumerisme manusia. Di sinilah nampak manusia melakukan pengingkaran akan status quo-nya sebagai kerabat kerja Allah yang seharusnya memanfaatkan dan mengembangkan alam untuk kebutuhannya. Konsumerisme merupakan kebiasaan memenuhi keinginan diri secara berlebihan, sebuah eksploitasi besar-besaran dan tentunya mengandung unsur kenikmatan (pleasure principle). Ini sungguh merupakan suatu keprihatian bersama dan mesti ada kesadaran kolektif untuk memeranginya.

Kata kunci : ekospiritualitas, ekologi, eksploitasi, krisis, eksistensi,konsumerisme

\section{PUNAHNYA KEANEKARAGAMAN HAYATI}

Seiring dengan meningkatnya jumlah penduduk, disertai oleh perkembangan politik dan ekonomi dalam beberapa masa, meningkat pula kebutuhan terhadap lahan untuk berbagai kepentingan. Kebutuhan atas lahan yang meningkat ini akhirnya cenderung memaksa terjadinya perubahan terhadap fungsi kawasan hutan untuk dikonversi menjadi berbagai jenis kebutuhan. Hal inilah yang menyebabkan semakin berkurangnya jumlah areal hutan dari tahun ke tahun. Jika pada tahun 1950, Indonesia diperkirakan masih memiliki 145 juta hektar hutan primer, dan pada tahun 1980 diperkirakan masih ada sekitar 143,8 juta hektar, namun saat ini, perkiraan sementara luas hutan perawan yang tersisa, menurut Mantan Menteri Kehutanan Zulkifli Hasan, hanyalah sekitar 22 juta hektar. Ini berarti total luas deforestasi selama kisaran 30 tahun telah mencapai 120 juta hektar. ${ }^{1}$ Suatu proses perusakan yang luar biasa.

Jika wilayah hutan di Indonesia mengalami kerusakan, maka tentu rusaklah pula segala jenis kekayaan keanekaragaman hayati yang ada. Tidaklah mengherankan jika dewasa ini Indonesia juga diberitakan sebagai negara yang mengalami kepunahan flora dan fauna terbesar di dunia. Berkenaan dengan kepunahan berbagai jenis makhluk hidup di Indonesia ini, menurut data yang tertera dalam Peraturan Pemerintah Republik Indonesia No. 7 Tahun 1999, disebutkan bahwa jumlah spesies hewan Indonesia yang terancam punah sebanyak 236 spesies. $^{2}$

1) Polusi Sebagai Dampak dari Sikap Kecerobohan 
Salah satu studi melaporkan bahwa Indonesia menjadi negara dengan tingkat polusi udara tertinggi ketiga di dunia. World Bank menempatkan Jakarta menjadi salah satu kota dengan kadar polutan/partikulat tertinggi setelah Beijing, New Delhi dan Mexico City. ${ }^{3}$ Dari semua penyebab polusi udara yang ada, emisi transportasi terbukti sebagai penyumbang pencemaran udara tertinggi di Indonesia, yakni sekitar 85\%. Hal ini diakibatkan oleh laju pertumbuhan kepemilikan kendaraan bermotor yang tinggi. Sebagian besar kendaraan bermotor itu menghasilkan emisi gas buang yang buruk, baik akibat perawatan yang kurang memadai ataupun dari penggunaan bahan bakar dengan kualitas kurang baik (misalnya kadar timbal yang tinggi). Selain itu, kebakaran hutan dan industri juga turut berperan. Selain terhadap udara, pencemaran air di Indonesia pun saat ini perlu mendapatkan perhatian seksama. Pencemaran air ini sebagian besar diakibatkan oleh aktifitas manusia yang meninggalkan limbah pemukiman, limbah pertanian, dan limbah industri termasuk pertambangan. ${ }^{4}$

2) Bencana dan Kesimpangsiuran Mekanisme Kehidupan

Hal penting yang juga perlu mendapatkan perhatian khusus adalah bahwa: sejak akhir tahun 2009 Indonesia dapat disebut sebagai "Negeri Seribu Bencana".5 Menurut penelitian yang dilakukan oleh United Nations International Stategy for Disaster Reduction (UNISDR; Badan PBB untuk Strategi Internasional Pengurangan Risiko Bencana), Indonesia merupakan negara yang paling rawan bencana alam di dunia. Berbagai bencana alam mulai gempa bumi, tsunami, letusan gunung berapi, banjir, tanah longsor, kekeringan, dan kebakaran hutan seringkali terjadi di Indonesia. Bahkan untuk jenis bencana tanah longsor, Indonesia menduduki peringkat pertama di dunia, mengungguli India, China, Filipina, dan Ethiopia. Sedangkan untuk jenis bencana banjir, Indonesia menduduki peringkat ke6, setelah Bangladesh, India, China, Vietnam, dan Kamboja. ${ }^{6}$

Menurut Kepala Pusat Data Informasi dan Humas Badan Nasional Penanggulangan Bencana (BNPB), Dr Sutopo Purwo Nugroho, trend bencana di Indonesia, khususnya bencana hidrometeorologi, seperti: banjir, kekeringan, tanah 
longsor, puting beliung, dan gelombang pasang merupakan jenis bencana yang dominan di Indonesia. Bencana hidrometeorologi ini terjadi rata-rata hampir 70\% dari total bencana di Indonesia setiap tahunnya. Bahkan, khususnya di tahun 2012 hingga 2013, malah 96\% kejadian bencana didominasi oleh bencana hidrometeorologi. ${ }^{7}$

Dapat dipastikan bahwa setiap tahun, bencana banjir memang selalu melanda Indonesia. Maka tak mengherankan jika hingga di akhir tahun 2012, Kementerian Kesejahteraan Rakyat menyatakan bahwa banjir merupakan bencana nomor satu yang paling sering terjadi Indonesia. ${ }^{8}$ Kecenderungannya, bencana yang satu ini bukannya semakin mereda, melainkan semakin bertambah sering terjadi setiap tahunnya. Hal ini bisa dicermati berikut: bahwa ketika memasuki tahun 2013, baru di bulan Januari saja, Badan Nasional Penanggulangan Bencana (BNPB) telah mencatat terjadinya 36 bencana banjir di seluruh penjuru Indonesia, dengan korban 61 jiwa meninggal, 110.129 orang menjadi pengungsi, dan 14.602 bangunan rusak. ${ }^{9}$

Selain bencana banjir, di sisi yang lain, hal yang bertolak belakang adalah bahwa jumlah sumber-sumber air di Indonesia juga menjadi banyak berkurang. Berdasarkan perhitungan kebutuhan air yang dilakukan Ditjen Sumber Daya Air, Kementerian Pekerjaan Umum, Pulau Jawa (yang memiliki populasi dan industri tinggi), Bali, dan Nusa Tenggara Timur telah mengalami defisit air sejak beberapa tahun terakhir, terutama pada musim kemarau. Defisit air ini akan terus bertambah parah akibat pertambahan penduduk dan meningkatnya kegiatan ekonomi. Gubernur Jawa Timur, Soekarwo, malah pernah mengatakan, bahwa dari 117 mata air yang ada di Jawa Timur, kini hanya tersisa 53 sumber. Bahkan, ketika musim kemarau datang, sumber-sumber air ini hanya tersisa tiga. Namun, tak hanya di Jawa Timur, krisis air bersih juga terjadi di banyak kota di Indonesia, termasuk di DKI Jakarta. Data penelitian Walhi menunjukkan bahwa dari 125 juta $(65 \%)$ penduduk Indonesia tinggal di Pulau Jawa dengan kapasitas kandungan air yang hanya $4,5 \%$ saja. ${ }^{10}$ Tentu hal itu tidak menjamin adanya daya dukung kehidupan. 
Patut disesalkan, jika 70\% dari seluruh bencana yang sering terjadi itu adalah jenis bencana hidrometeorologi — khususnya banjir dan kekeringan. Padahal bencana tersebut secara umum hanya dapat terjadi karena adanya kecerobohan manusia, yakni: terjadinya penebangan hutan secara liar tanpa disertai reboisasi, pembangunan secara serampangan tanpa mempertimbangkan perlunya daerah resapan air, pendangkalan sungai karena pembuangan sampah sembarangan, pembuatan saluran air yang tidak memenuhi syarat, dan pembuatan tanggul yang kurang baik. Jika ada upaya serius, sebetulnya jenis bencana seperti ini masih memungkinkan untuk dihindari.

Selain munculnya berbagai jenis bencana itu, hal memprihatinkan lain adalah berkenaan dengan terjadinya kesimpangsiuran mekanisme kehidupan. Adanya kesimpangsiuran mekanisme kehidupan ini tak lain diakibatkan oleh karena ketidakmampuan habitat dalam menyediakan daya dukung terhadap kehidupan, sehingga memunculkan reaksi destruktif — terutama dari para satwa - terhadap makhluk lain. Hal ini dapat diperhatikan melalui peristiwa-peristiwa sebagai berikut: Lebih dari 40 ekor gajah dikabarkan sering menghancurkan areal perkebunan dan menelan hasil panen di desa Balaimakam, Riau. Area yang tadinya hutan itu telah diubah menjadi perkebunan kelapa sawit dan daerah pemukiman, yang dengan demikian mengurangi habitat gajah. Konflik antara manusia dan gajah yang telah terjadi sejak 1988, dikarenakan mereka memperebutkan daerah hunian yang sama. Tiga orang telah terbunuh dan seorang terluka semenjak terjadinya konflik itu. Kabar lain juga menyebutkan bahwa lenyapnya daerah hutan hujan bersamaan dengan punahnya satwa liar di Riau, memaksa para Harimau Sumatra mencari makan di luar habitat mereka. Kenyataan itu menjadikan faktor penyebab terbunuhnya 14 orang di propinsi itu sejak Januari 2002. ${ }^{11}$

Tak hanya itu, kesimpangsiuran mekanisme kehidupan ini pun dapat muncul dalam bentuk terjadinya perubahan perilaku hewan, karena diakibatkan oleh adanya polusi atau pencemaran dari bahan-bahan kimia. Contoh-contoh perubahan perilaku telah dialami oleh beberapa satwa, di antaranya adalah: Nyamuk demam berdarah, Aedes aegypti, yang sebelumnya hanya suka berada di 
air bersih, tetapi sekarang juga bisa tinggal di air yang sudah terpolusi oleh deterjen, kaporit, dan kotoran hewan, bahkan air comberan. Lain dari itu, burung Jalak jantan yang terpengaruh insektisida akan mengalami penurunan kemampuan berkicau, terbang, dan mencari makan hingga 50\%. ${ }^{12}$ Lebih parah lagi, bahwa polusi dari bahan kimia yang tak terkendali ini juga mampu menyebabkan terjadinya perubahan fisik pada tubuh hewan, sebagai contohnya: salah satu obat pembunuh rumput yang paling umum digunakan, dapat mengubah katak jantan menjadi betina. Zat atrazine yang terkandung dalam obat pembunuh rumput inilah yang diduga menjadi penyebab utama merosotnya jumlah hewan amphibi di seluruh dunia. Padahal, Uni Eropa telah melarang penggunaan atrazine pada sektor pertanian sejak tahun $2004 .^{13}$

Demikianlah kenyataan atau konteks yang sedang dihadapi di Indonesia, yakni bahwa hampir setiap hari terdengar kabar tentang bencana ekologis yang terjadi di seluruh negeri: penipisan berbagai sumber daya, kepunahan spesies, meningkatnya polusi, terjadinya berbagai bentuk bencana dan kesimpangsiuran mekanisme kehidupan. Segala bentuk krisis ekologis ini sesungguhnya tak lain adalah akibat dari adanya kesalahpahaman dan penafsiran yang keliru terhadap hubungan antara manusia dengan alam, yakni dengan sesama ciptaan itu sendiri. Namun, kebanyakan dari manusia selalu mencoba untuk mengabaikan itu semua. Maka inilah akar sesungguhnya dari krisis ekologis, yakni: adanya penghindaran dan penolakan. Maka dengan mempertimbangkan hal itu, memang sudah saatnya dibutuhkan suatu jenis spiritualitas tertentu yang diyakini dapat memotivasi tindakan seseorang untuk melakukan suatu perbedaan.

\section{EKOSPIRITUALITAS SEBAGAI SARANA DALAM MEMUPUK KESADARAN EKOLOGIS}

Konteks Indonesia yang tengah berada dalam situasi krisis ekologis, tentu yang sangat dibutuhkan adalah terbentuknya suatu kesadaran — dalam wujud sebuah spiritualitas — yang mampu memotivasi munculnya respon manusia dalam menanggapi kenyataan/konteks yang sedang dihadapi dalam hidupnya. Jenis spiritualitas seperti ini tak lain adalah berupa ekospiritualitas, yang 
berdasarkan pada pemikiran analitis yang berangkat dari konteks, yang diharapkan mampu menjadi jawaban terhadap segala permasalahan yang sedang diungkapkan oleh konteks. Sebab, ketika kehancuran yang ditimbulkan oleh krisis ekologis itu semakin parah, maka seharusnya manusia pun menjadi semakin terdesak untuk memeriksa kembali pemahaman mereka mengenai alam, di mana mereka berada, dan hubungan mereka dengannya. Ini adalah panggilan untuk memeriksa kembali hubungan manusia baik dengan seluruh ciptaan maupun dengan Sang Pencipta.

Yang dimaksud dengan spiritualitas sesungguhnya adalah suatu kehidupan yang dicirikan melalui bentuk kesungguhan perilaku transendensi diri — yakni kapasitas seseorang untuk dapat melampaui diri-nya sendiri — dalam mencapai "nilai-nilai utama", yang hanya dapat diraih melalui pengalaman pribadi dalam bentuk hubungan antara dirinya, baik dengan Sang Adikodrati (Tuhan) maupun dengan ciptaan yang lain - agar melalui pengalaman tersebut manusia mampu mendapatkan pengetahuan akan Allah, cinta/kasih dan kehendak-Nya, sehingga hidup yang dialami selanjutnya tak lagi terbelenggu oleh segala hal yang bersifat materi.

Kata spiritualitas memiliki hubungan dengan kata Spirit atau Roh yaitu daya kekuatan yang menghidupkan atau menggerakkan. Spiritualitas dapat diartikan sebagai kekuatan atau Roh yang memberi daya tahan kepada seseorang atau kelompok untuk mempertahankan, mengembangkan dan mewujudkan kehidupan. ${ }^{14}$ Spiritualitas menjadi semakin penting dalam kehidupan manusia dewasa ini karena menjadi barometer hubungan pribadi dengan Sang Khalik yang seyogianya melahirkan manusia yang memiliki moralitas, cara pandang dan hati yang baik serta mencerminkan sifat dan karakter Sang Khalik yang dengannya manusia membangun relasi dengan sesama ciptaan. Dalam arus pemikiran konservatif, menurut Pieris pernyataan Gereja resmi yang dikeluarkan cenderung untuk mengambil pandangan sempit yang melihat kontemplasi sebagai makna tunggal spiritualitas, dan semua bentuk "liturgi" dan "keterlibatan" kristiani tanpa kontemplasi dianggap tidak spiritual. Padahal spiritualitas tidak hanya berhubungan dengan hal-hal yang rohaniah semata sebab spiritualitaspun dapat 
menjadi sumber kekuatan untuk menghadapi penganiayaan, kesulitan, penindasan dan kegagalan yang dialami oleh orang-orang atau kelompok yang sedang mewujudkan cita-cita atau tujuannya. Senada dengan itu Joann Wolski Conn ${ }^{15}$ melihat spiritualitas sebagai pengalaman hidup dan sebagai bidang studi tidak lagi diidentifikasi hanya dengan asketisisme dan mistisisme atau dengan mengamalkan kebaikan dan cara berdoa, tetapi keseluruhan perkembangan pembangunan manusia.

Spiritualitas bukan semata urusan langit-langit Surga namun ternyata juga berhadapan dengan realitas hidup di mana intensitas kerusakan ekologi semakin tinggi dan intensitas kepedulian manusia untuk melestarikan ekologi mencapai titik nadir manusia tidak lagi mengindahkan relasi dengan sang pencipta dan sesama ciptaan. Kebenaran sendiri dan nafsu menguasai dan menaklukkan alam demi memenuhi berbagai keinginan manusia acapkali menjadi pandu dalam membangun dan mengembangkan relasi yang ada sehingga kerusakan alam, akibat-akibatnya yang mendatangkan bencana atas kehidupan adalah realitas yang berlangsung sedemikian massifnya.

Spiritualitas sebenarnya dimotivasi oleh gerakan hati, kontemplatif, dan terarah, dalam sebuah perjalanan hidup untuk memeriksa kembali hubungan diri, baik dengan seluruh ciptaan maupun dengan Sang Pencipta. Dalam perspektif Kristen, kegiatan pemeriksaan kembali terhadap hubungan antara diri dengan lingkungannya semacam ini berlangsung dalam konteks ekoteologi dan etika lingkungan, yang pada gilirannya berakar pada tujuan dan hakekat hidup, khususnya tujuan dan hakekat Penciptaan. ${ }^{16}$ Ketika tujuan dan hakekat hidup, khususnya tujuan dan hakekat Penciptaan, itu mulai dipahami, maka berarti manusia mulai menemukan "nilai-nilai utama", yang seharusnya diraih melalui pengalaman pribadi dalam bentuk hubungan konkrit antara dirinya, baik dengan Sang Adikodrati (Tuhan) maupun dengan ciptaan yang lain. Itu dapat terjadi dalam diri manusia jika seseorang mengalami perkembangan dalam proses :

$\checkmark$ kesadaran diri;

$\checkmark$ pertimbangan serius terhadap akibat yang akan diterima oleh segala sesuatu — dalam hal ini: sesama ciptaan; 
perasaan keterkaitan antara dirinya dengan segala sesuatu secara universal. $^{17}$

Adanya ketiga prasyarat berkenaan dengan spiritualitas ini mengisyaratkan bahwa kesadaran manusia akan pentingnya melestarikan ekologi merupakan bentuk respon manusia dalam menanggapi kenyataan/konteks yang sedang dihadapi dalam hidupnya di mana alam selalu dianggap sebagai objek pemuas. Berkenaan dengan "nilai-nilai utama" yang hendak dicapai melalui pengalaman hidup manusiawi itu - yang tak lain merupakan tujuan dan hakekat Penciptaan maka ketiga prasyarat dari perjalanan spiritual, seperti yang telah diuraikan di atas, dapat digunakan untuk mengeksplorasi suatu bentuk spiritualitas yang disebut dengan ekospiritualitas — yakni: sebuah spiritualitas yang memotivasi kepedulian terhadap lingkungan. ${ }^{18}$

Hal ini penting sebab sikap iman Kristiani terhadap alam semesta berubah dari waktu ke waktu. Pada masa pramodern, manusia hidup dekat dengan alam. Hal ini tercermin antara lain dalam spiritualitas model Benedictan. Contoh spiritualitas yang dekat dengan alam ditunjukkan oleh Fransiskus Asisi (11811226). Namun sesudah abad-abad gelap (dark ages) atau abad pertengahan, berkembanglah sekolah katedral dan universitas yang mengembangkan ilmu pengetahuan; alam dipelajari secara ilmiah. Dengan adanya pembaruan politik dan sosial pada abad 18, manusia makin merasa berkuasa dan dapat menentukan arah hidup dan dunia ini. Ditambah dengan perkembangan yang dibawa ilmuwan, teknologis, dan insinyur pada abad 19, alam semakin dipandang sebagai obyek yang dipelajari dan dimanfaatkan. ${ }^{19}$ Sikap memisahkan manusia dari alam, dan menaklukkan serta menguasai alam, merupakan masalah teologis dan spiritual. Maka diperlukan suatu model spiritualitas baru, yaitu spiritualitas yang cinta lingkungan (sensitif terhadap ekologi).

Spiritualitas ini dibangun dengan dasar penghayatan iman bahwa semua ciptaan diselamatkan dan dibaharui oleh Tuhan. Pembaharuan itu menciptakan kehidupan yang harmonis. Spiritualitas ekologis mempunyai dasar pada pengalaman manusiawi yang berhadapan dengan kehancuran lingkungan hidup sekaligus berhadapan dengan pengalaman akan yang Mahakudus, yang mengatasi 
segalanya. Dalam pengalaman ini kita dipanggil untuk secara kreatif memelihara kualitas kehidupan, dipanggil untuk bersama Sang Penyelenggara hidup ikut serta mengusahakan syalom, kesejahteraan bersama dengan seluruh alam.

\section{KELEMAHAN EKOSPIRITUALITAS MASA KINI}

Corak pemikiran analitis yang berangkat dari konteks, yakni berupa krisis ekologis yang selama ini dialami, memang merupakan sebuah gaya pemikiran yang baik. Gaya pemikiran seperti ini memang umum diterapkan pada masa kini, sebab itu sesuai dengan metode penelitian yang dianggap ilmiah menurut model pemikiran zaman sekarang. Segala bentuk konsep pemikiran teologis pun tak lepas dari metode yang berlangsung seperti ini, yakni yang dilakukan dengan tahap-tahap: pertama, berawal dari pengamatan terhadap konteks, yakni: situasi sosial. Di sini sang pengamat "melihat" dan "mendengarkan" apa yang sedang terjadi dalam masyarakat di lingkungannya. Kedua, dilakukannya proses analisis terhadap data informatif dari hasil pengamatan. Di sini sang pengamat akan menemukan makna pola-pola tingkah laku dari budaya dalam masyarakat yang telah terstruktur. Ketiga, dilaksanakanlah sebuah refleksi teologis, yakni suatu upaya untuk membangun interelasi kritis antara situasi riil (aktual) dengan normanorma (ajaran) gereja sebagai situasi ideal. Di sini, sang pengamat mendialogkan antara fakta empiris dengan tradisi iman kristen, dengan sebuah perspektif tertentu yang dalam hal ini: perspektif ekoteologis. Keempat, ditentukannya sebuah perencanaan aksi/tindakan. Ini adalah upaya sang pengamat untuk membangun suatu gagasan ideal sebagai hasil dari interelasi kritis yang bertolak dari situasi sosial di tengah masyarakat dan acuan normatif dari tradisi gereja. Pada kenyataannya, aksi/tindakan ini pasti akan dilaksanakan dalam sebuah konteks kehidupan, sehingga dengan demikian proses ini diharapkan berlangsung terusmenerus layaknya sebuah siklus. Inilah yang biasa dikenal dengan metode penelitian dengan menggunakan lingkaran hermeneuti ${ }^{20}$ atau lingkaran pastoral ${ }^{21}$.

Dengan gaya pemikiran yang demikian, maka akhirnya Ekospiritualitas Masa Kini umumnya mempunyai 3 ciri pokok, yakni: 
- Mempunyai titik berangkat yang bermula dari konteks kehidupan masa kini, yakni: krisis ekologis yang sedang melanda dunia; dan situasi sosial masyarakat, yakni: kekuatiran manusiawi yang berkaitan dengan kehancuran bumi.

- Mempunyai titik berat pada soal penentuan strategi menyangkut proses pengelolaan sumber daya alamiah, dan penentuan kebijakan politis. Kedua hal yang menjadi titik berat ini dianggap sangat penting, sebab sangat berkaitan dengan konteks dan diharapkan mampu menjawab segala permasalahan yang diungkapkan oleh konteks. Oleh karenanya, maka keduanya tak lain adalah tujuan utama dari gerakan ekospiritualitas di zaman modern itu sendiri.

- Menonjolkan sikap keterbukaan untuk menganggap alam sebagai sesama ciptaan, tetapi sekaligus tetap menempatkan mereka, sesama ciptaan nonmanusia itu, sebagai komoditas konsumtif dan komoditas profit ${ }^{22}$, demi terlaksananya suatu program pembangunan yang berkelanjutan.

Tentu, dengan ke-3 ciri pokok ini, membuat ekospiritualitas masa kini menjadi sesuai untuk diterapkan menurut zamannya. Bentuk spiritualitas semacam ini diharapkan mampu memberikan jawaban terhadap permasalahan dunia secara kontekstual di masa kini. Namun, ketika ekospiritualitas masa kini selalu berangkat dari konteks berupa adanya krisis ekologis yang sedang melanda dunia dan kekuatiran manusiawi yang berkaitan dengan kehancuran bumi, maka jenis ekospiritualitas seperti ini akhirnya terkesan tendensius, yakni cenderung berpihak pada kondisi ekologis yang sedang dialaminya saja dan hanya berpihak pada situasi sosial masyarakat dengan berbagai kekuatiran manusiawi yang berkaitan dengan kehancuran bumi. Tentu melalui kesan yang tendensius ini maka jawaban yang segera dibutuhkan hanyalah terpaku kepada penanggulangan krisis ekologis yang sedang terjadi dan upaya meredam kekuatiran mengenai kehancuran bumi.

Berikutnya, ketika titik berat ekospiritualitas itu selalu terarah pada soal penentuan strategi menyangkut proses pengelolaan sumber daya alamiah, dan penentuan kebijakan politis, maka implementasi konkrit dari spiritualitas semacam ini terkesan mempunyai jangkauan yang terlalu jauh dan mungkin hanya 
dapat ditangani oleh pihak-pihak tertentu (yang mempunyai kekuasaan di bidang politik dan perekonomian). Jika hal ini yang betul-betul diterapkan, maka seringkali terjadi aksi/tindakan sederhana sehari-hari akan dilupakan. Orang hanya akan sibuk dengan perkara yang besar-besar, sedangkan abai terhadap perkara sederhana, yang menuntut perhatian setiap hari. Selain itu, pemakaian istilah 'strategi pengelolaan sumber daya alamiah' pun cenderung mempunyai kesan yang kurang ekologis. Ini tetap mengandaikan bahwa alam hanyalah sekedar suatu sumber daya, hanyalah sekedar obyek yang perlu dikelola.

Hal terakhir, ketika Ekospiritualitas Masa Kini itu masih menonjolkan sikap yang menempatkan sesama ciptaan non-manusia sebagai komoditas konsumtif dan komoditas profit, demi terlaksananya suatu program pembangunan yang berkelanjutan, maka berarti bahwa sikap semacam ini masih terarah untuk memandang sesama ciptaan non-manusia itu hanya dari nilai manfaatnya saja. Memang tak dapat dipungkiri bahwa dalam ikatan kehidupan bersama tak dapat dihindarkan terjadinya suatu hubungan simbiosis mutualis, yakni hubungan yang saling menghidupi, hubungan yang saling memanfaatkan. Dengan demikian maka setiap unsur ciptaan cenderung mempunyai instrumental value (nilai instrumental/nilai manfaat) bagi ciptaan yang lain. Namun, sesama ciptaan tidak seharusnya hanya dipandang dari nilai manfaat-nya saja, sehingga lalu manusia dapat berbuat dengan seenaknya. Tetaplah bahwa sesama ciptaan seharusnya dipandang sebagai bagian dari unsur kosmik yang mempunyai inherent value (nilai bawaan) dan intrinsic value (nilai hakiki) yang membuat dirinya harus dihormati karena keberadaannya. Alam mempunyai maknanya bukan karena fungsi pelayanannya untuk umat manusia, tetapi karena mereka merupakan ekspresi dari berbagai bentuk kehadiran kebaikan Allah. Hubungan manusia dan ciptaan non-manusia seharusnya lebih dari sekedar saling ketergantungan. Perlu diakui juga bahwa sikap yang terlalu menekankan kepentingan pembudidayaan komoditas konsumtif dan komoditas profit pun dapat dipakai untuk upaya konservasi alam, namun hal ini bukanlah merupakan sikap yang bersumber pada pengakuan terhadap adanya unsur kesakralan dalam diri sesama ciptaan. Padahal tanpa adanya pengakuan terhadap adanya unsur kesakralan dalam diri sesama 
ciptaan, tentu akan membuat ekospiritualitas tersebut menjadi suatu bentuk pengabaian terhadap peran Allah dalam karya penciptaanNya.

\section{EKOSPIRITUALITAS YANG IDEAL}

Dengan mencermati metode berpikir Ekospiritualitas Masa Kini yang seperti itu, maka alangkah lebih baik jika model ekospiritualitas yang seperti itu mau mempertimbangkan berbagai aspek yang ditawarkan oleh model Ekospiritualitas Masa Lalu, yakni jenis ekospiritualitas sebagaimana yang pernah dikembangkan oleh para tokoh kekristenan lama di antaranya: Coenraad Laurens Coolen dan Fransiskus Assisi khususnya melalui Doa kepada Dewi Sri-Sêdana ${ }^{23}$, Doa kepada Gunung Sêmèru ${ }^{24}$, dan Gita Sang Surya adalah corak ekospiritualitas yang mempunyai cirinya sendiri, sedikit berbeda jika dibandingkan dengan Ekospiritualitas Masa Kini, namun bukan berarti kedua jenis ekospiritualitas itu bertolak belakang dan tidak dapat dipertemukan. Oleh sebab itu baiklah kiranya jika ada upaya untuk menggabungkan, bahkan menyatukan, kedua jenis ekospiritualitas tersebut, sebab tentu masing-masing jenis ekospiritualitas ini akan mampu memperkaya jangkauan pandang antara yang satu terhadap yang lain. Keduanya tentu akan saling melengkapi satu dengan yang lain, menjadi sebuah bentuk Ekospiritualitas yang holistik, sehingga akhirnya memampukan seorang beriman untuk memiliki suatu jenis ekospiritualitas dengan 'nilai-nilai utama', yang dapat diterapkan melalui pengalaman pribadinya, hingga dapat memotivasinya untuk semakin memperbaiki hubungan antara dirinya dengan Tuhan maupun dengan sesama ciptaan dalam kasih.

Melalui hasil penafsiran yang seksama ${ }^{25}$ terhadap karya-karya teologis mereka, dapatlah disimpulkan bahwa pemahaman yang ditawarkan dalam ekospiritualitas CL Coolen dan Fransiskus Assisi adalah sebagai berikut: Pertama, karya teologis para tokoh ini berangkat dari pemahaman, iman dan teologi tentang keberadaan Tuhan sebagai Sang Pencipta, Sang Pemilik, dan Sang Pemelihara seluruh ciptaan. Kedua, karya teologis para tokoh ini menonjolkan adanya sikap keterbukaan untuk memandang bahwa alam (segala ciptaan non manusia) juga merupakan sesama yang menjadi simbol dari kehadiran Allah 
dalam kehidupan. Alam, sebagai sesama ciptaan itu, mempunyai unsur kesakralan dan menjadi gambaran dari kehadiran Allah yang menghidupkan, menaungi, serta memelihara, sehingga segala bentuk eksploitasi ${ }^{26}$ apapun dianggap sebagai suatu penodaan terhadap kesakralan simbol ilahi tersebut. Ketiga, karya teologis para tokoh ini mengusulkan diupayakannya suatu jalinan kepedulian di antara sesama ciptaan, antara manusia dan ciptaan lain, melalui terwujudnya sikap saling menghargai dan menghormati dalam kesetaraan. Keempat, karya teologis para tokoh ini menekankan terwujudnya aksi/tindakan sederhana sehari-hari berkenaan dengan kasih, penghargaan dan penghormatan yang tulus terhadap sesama ciptaan agar hubungan komunikatif antar ciptaan dalam kesetaraan mampu berjalan secara harmonis.

Seperti telah disinggung sebelumnya, bahwa Ekospiritualitas Masa Kini yang umumnya berangkat dari konteks krisis ekologis dan kekuatiran manusiawi yang berkaitan dengan kehancuran bumi merupakan jenis ekospiritualitas yang baik, sebab inilah yang memang umum diterapkan pada masa kini, yang mencakup karakteristik metode penelitian yang dianggap ilmiah menurut model pemikiran zaman sekarang. Namun, jenis ekospiritualitas seperti ini terkesan tendensius, yakni cenderung berpihak pada kondisi ekologis yang sedang dialaminya saja dan berpihak pada situasi sosial masyarakat dengan berbagai kekuatiran manusiawi yang berkaitan dengan kehancuran bumi. Tentu melalui kesan yang tendensius ini jawaban yang segera dibutuhkan hanyalah terpaku kepada penanggulangan krisis ekologis yang sedang terjadi dan upaya meredam kekuatiran mengenai kehancuran bumi. Maka akan menjadi lebih netral, dan tidak terlalu bersifat tendensius, jika jenis ekospiritualitas seperti ini bertemu dengan ekospiritualitas dari kedua tokoh, yang bukannya berangkat dari krisis ekologis, namun bertolak dari: pemahaman, iman dan teologi tentang keberadaan Tuhan sebagai Sang Pencipta, Sang Pemilik, dan Sang Pemelihara. Memang, ekospiritualitas kedua tokoh ini tidak mungkin berangkat dari pengalaman berkenaan dengan suatu bentuk krisis ekologis tertentu sebab memang krisis semacam itu belum terjadi sedemikian parah hingga paroh kedua abad ke-19. Namun ternyata bukan berarti di zaman mereka spiritualitas yang memotivasi 
kepedulian terhadap lingkungan belum pernah ada. Ini nyata terbukti melalui isi doa dan nyanyian CL Coolen dan Fransiskus Assisi, dimana karya teologis mereka yang secara umum mengusulkan terjadinya suatu hubungan saling menghargai dan menghormati di antara sesama ciptaan selalu berangkat dari teologi tentang keberadaan Tuhan sebagai Sang Pencipta, Sang Pemilik, dan Sang Pemelihara segala ciptaan.

Titik berat ekospiritualitas itu tidak lagi hanya terarah pada soal penentuan strategi menyangkut proses pengelolaan sumber daya alamiah, dan penentuan kebijakan politis. Namun, seperti yang telah dibahas sebelumnya, penentuan strategi pengelolaan sumber daya alamiah dan kebijakan politis itu terkesan mempunyai jangkauan yang terlalu luas dan mungkin hanya dapat ditangani oleh pihak-pihak tertentu (yang mempunyai kekuasaan di bidang politik dan perekonomian). Jika hal ini yang betul-betul diterapkan, maka seringkali terjadi aksi/tindakan sederhana sehari-hari akan dilupakan. Orang hanya akan sibuk dengan perkara yang besar-besar, sedangkan perkara sederhana, yang menuntut perhatian setiap hari menjadi terabaikan. Maka, alangkah lebih baik jika jenis ekospiritualitas seperti ini bertemu dengan ekospiritualitas dari kedua tokoh, yang menitikberatkan pada berlangsungnya aksi/tindakan sederhana sehari-hari, baik secara individual maupun sebagai komunitas, sebagai wujud kesadaran akan kasih, penghargaan dan penghormatan terhadap sesama ciptaan. Tujuan utamanya bukanlah semata-mata mengadakan konservasi alam, apalagi konservasi sumber daya alam, melainkan upaya memotivasi diri dan umat untuk mampu memberlakukan kasih, penghargaan dan penghormatan yang tulus terhadap sesama ciptaan. Dengan demikian, jika hal itu tercapai, maka dengan sendirinya proses konservasi alam akan terwujud - meski hal itu bukanlah yang menjadi tujuan, namun lebih dari itu: hubungan komunikatif antar ciptaan, antara subyek dan subyek dalam kesetaraan, mampu berjalan secara harmonis. Tentu ketika kedua tujuan ini digabungkan, maka akan menjadi semakin beragamlah arah yang hendak digapai, yakni: baik jangkauan luas berupa penentuan strategi pengelolaan sumber daya alamiah dan kebijakan politis, maupun jangkauan pendek berupa 
tindakan sederhana sehari-hari, sebagai wujud kesadaran akan kasih, penghargaan dan penghormatan terhadap sesama ciptaan.

Hal terakhir, jika titik berat dari ekospiritualitas tersebut mempunyai keragaman yang demikian, maka sikap yang ditonjolkan tidak lagi menempatkan sesama ciptaan non-manusia hanya sekedar sebagai sebagai komoditas konsumtif dan komoditas profit. Memang, seperti paparan sebelumnya, tak dapat dipungkiri bahwa dalam ikatan kehidupan bersama tentu membutuhkan terjadinya suatu hubungan simbiosis mutualis, yakni hubungan yang saling menghidupi, hubungan yang saling memanfaatkan. Namun, sesama ciptaan tidak seharusnya hanya dipandang dari nilai manfaat-nya saja, sehingga lalu manusia dapat berbuat dengan seenaknya. Tetaplah bahwa sesama ciptaan seharusnya dipandang sebagai bagian dari unsur kosmik yang mempunyai inherent value (nilai bawaan) dan intrinsic value (nilai hakiki) yang membuat dirinya harus dihormati karena keberadaannya. Alam mempunyai maknanya bukan karena fungsi pelayanannya untuk umat manusia, tetapi karena mereka merupakan ekspresi dari berbagai bentuk kehadiran kebaikan Allah. Hubungan manusia dan ciptaan non-manusia seharusnya lebih dari sekedar saling ketergantungan. Perlu diakui juga bahwa sikap yang terlalu menekankan kepentingan pembudidayaan komoditas konsumtif dan komoditas profit pun dapat dipakai untuk upaya konservasi alam, namun hal ini bukanlah merupakan sikap yang bersumber pada pengakuan terhadap adanya unsur kesakralan dalam diri sesama ciptaan. Padahal tanpa adanya pengakuan terhadap adanya unsur kesakralan dalam diri sesama ciptaan, tentu akan membuat ekospiritualitas tersebut menjadi suatu bentuk pengabaian terhadap peran Allah dalam karya penciptaanNya. Maka, alangkah lebih baik jika jenis ekospiritualitas seperti ini bertemu dengan ekospiritualitas dari kedua tokoh, yang mengutamakan adanya sikap keterbukaan untuk memandang alam sebagai sesama ciptaan, sekaligus menjadi simbol dari kehadiran Allah dalam kehidupan. Alam, sebagai sesama ciptaan itu, mempunyai unsur kesakralan dan menjadi gambaran dari kehadiran Allah yang menghidupkan, menaungi, serta memelihara, sehingga segala bentuk eksploitasi apapun dianggap sebagai suatu penodaan terhadap kesakralan simbol ilahi tersebut. Ketika kedua sikap ini digabungkan, maka akan 
jelas bahwa pembudidayaan komoditas konsumtif dan komoditas profit terhadap alam yang sedang diupayakan itu jangan sampai berakar hanya pada keserakahan manusia, namun tetap berpegang pada motivasi yang mementingkan kebaikan bagi semua, kebaikan bagi seluruh ciptaan dan kemuliaan Tuhan.

\section{KESADARAN HAKIKI GEREJAWI}

Sudah selayaknya bahwa Gereja Protestan selalu ingat terhadap semboyan gerakan Reformasi, yakni: Ecclesia reformata semper reformanda, yang berarti : Gereja yang telah diperbaharui adalah Gereja yang (harus) terus-menerus memperbaharui diri. Pembaharuan diri itu dilakukan dengan jalan transformasi cara pandang, transformasi pengetahuan, seiring dengan konteks yang sedang dihadapi gereja dalam kehidupannya di tengah masyarakat. Namun kadangkala hal ini terjadi secara kebablasan, sehingga pembaharuan yang ada bukanlah membuat gereja menjadi semakin baik, tetapi malah sebaliknya. Ini terjadi karena hanya terlalu menitik-beratkan agar "seiring dengan konteks yang sedang dihadapi". Hal ini menandakan pemahaman terhadap konsep "pembaharuan secara kristiani" kurang mendapatkan perhatian serius. Tidak seharusnya pembaharuan itu akhirnya hanyalah untuk mencari jalan aman agar dapat bertahan dalam konteks masa kini atau hanya sekedar ada. Sebab sesungguhnya semboyan gereja-gereja Reformasi seperti penjelasan di atas tidak hanya berbunyi demikian, namun secara lengkap sebenarnya sebagai berikut: Ecclesia reformata semper reformanda secundum verbum Dei, yang bermakna: Gereja reformasi adalah Gereja yang (harus) terus-menerus memperbaharui diri sesuai dengan firman Tuhan.

Semangat reformasi gereja hendaknya menjadi nuansa baru dalam konteks kesadaran ekologis. Gereja yang ekologis mengguratkan makna kehidupan dan pembebasan dengan menaruh konsentrasi pada kelestarian alam. Manusia mesti memberikan kehidupan (bukan kematian) kepada komponen lingkungan hidup supaya bisa bertumbuh dan berkembang. Manusia membawa kemenangan demi terciptanya keselarasan dan keseimbangan ekosistem alam itu (aspek homeostatis). Terdapat kenyamanan dan keselamatan di dalam diri alam ciptaan. 
Gereja yang ekologis menandakan adanya pertalian khusus antara manusia dan alam lingkungan. Ini karena berbicara tentang ekologi berarti berbicara mengenai relasi antara manusia dan lingkungan kehidupannya. Terdapat jalinan intim dalam relasi itu sebab sejarah manusia tak pernah lepas dari keterikatannya dengan alam lingkungan.

Manusia perlu memiliki kesadaran bahwa dia adalah bagian yang tak terpisahkan dari alam. Dan sebagai bagian dari alam maka manusia harus kembali memulihkan kondisi alam yang telah dirusaknya, sebagai wujud dari tugas penatalayananya kepada alam dan sebagai respons imannya kepada Allah yang memberinya tugas dimaksud. Dalam kaitan itu manusia mesti belajar dari kebudayaan dan agama bangsa-bangsa di Timur yang melihat alam semesta sebagai entitas yang sakral. Hal ini bukan berarti bahwa manusia mendewakan alam, sebab secara teologis manusia melihat alam sebagai ciptaan Allah.

Gereja juga mesti memperlihatkan kesungguhan dan komitmen teologis terhadap mandat penatalayanan yang diterima dari Allah dengan melakukan aksiaksi nyata dalam upaya pemulihan dan pemeliharaan alam semesta. Dengan kata lain teologi tidak tinggal menjadi sebuah refleksi iman dalam wujud kata-kata semata, bukan juga teologi yang semata-mata memgarahkan perhatian dan pandangan ke Surga melainkan menatap ke bumi, ke realitas dunia huniannya yang makin menguatirkan. Teologi harus bermuara pada tindakan nyata atau tepatnya teologi harus menjadi sebuah gaya hidup (life style). Gereja yang terlibat dalam aksi-aksi nyata seperti misalnya kampanye-kampanye pemeliharaan ekologi, kampanye penggunaan bahan bakar ramah lingkungan, kampanye tertib membuang sampah, menghemat debit air, melakukan reboisasi atas hutan yang telah gundul sebagai wujud kesadaran bahwa efek rumah kaca itu disebabkan oleh akumulasi dari buangan gas $\mathrm{CO} 2$ serta kampanye penggunaan alat-alat rumah tangga yang sedikit menghabiskan energi dan kurang dalam pembuangan zat-zat beracun yang merusak lingkungan. Mengkampanyekan penanaman pohon dan tidak menebang pohon secara tidak bertanggung jawab. Penggunaan AC juga perlu dikurangi dan untuk itu perlu membuat rumah yang berventilasi agar tidak membutuhkan AC dan lain-lain sebagainya. 


\section{Catatan akhir}

${ }^{1}$ Aloysius Pieris, SJ, Berteologi dalam Konteks Asia, Kanisius, 1995, 21

${ }^{2}$ http://www.dephut.go.id/.../LAMPIRAN\%20PERATURAN\%20PEMERINTAH\%20REPUBLIK $\%$..., diunduh pada tanggal 19 Januari 2013

3 http://alamendah.wordpress.com/2009/09/23/tingkat-pencemaran-udara-di-indonesia/, diunduh pada tanggal 25 Januari 2013

${ }^{4}$ http://alamendah.wordpress.com/2010/08/01/pencemaran-air-di-indonesia/, diunduh pada tanggal 25 Januari 2015.

${ }^{5}$ http://www.beritaindonesia.co.id/berita-utama/negeri-seribu-bencana/, diunduh pada tanggal 19 April 2015

6 http://alamendah.org/2011/08/29/indonesia-negara-paling-rawan-bencana-alam/, diunduh pada tanggal 19 April 2015.

7 http://nasional.news.viva.co.id/news/read/387307-januari-2013--119-bencana-di-indonesia--126tewas, diunduh pada tanggal 23 April 2015

${ }^{8} \mathrm{http}: / / \mathrm{m} . \mathrm{merdeka} \cdot \mathrm{com} /$ peristiwa/banjir-jadi-bencana-nomor-satu-di-indonesia.html, diunduh pada tanggal 23 April 2015

9 http://nasional.news.viva.co.id/news/read/387307-januari-2013--119-bencana-di-indonesia--126tewas, diunduh pada tanggal 23 April 2015.

${ }^{10}$ http://sains.kompas.com/read/2010/08/26/16374722/Lahan.dan.Hutan.Kritis...Air.ttp://sains.kom pas.com/read/2010/08/26/16374722/Lahan.dan.Hutan.Kritis...Air.ttp://sains.kompas.com/read/20 10/08/26/16374722/Lahan.dan.Hutan.Kritis...Air.Krisis, diunduh pada tanggal 23 April 2015

${ }^{11}$ Disarikan dari http://www.thejakartapost.com, dari berbagai tanggal

$12 \mathrm{Http}: / / w w w . d u n i a e s a i . c o m /$ index.php/component/content/article/46-sains/309-polusi-memicuperilaku-aneh-pada-binatang.html, yang diunduh pada tanggal 27 April 2015

${ }^{13} \mathrm{http}$ ///www.republika.co.id/berita/pendidik..., diunduh pada tanggal 27 April 2015

${ }^{14}$ J.B.Banawiratma (eds.,) Spiritualitas Transformatif Suatu Pergumulan Ekumenis, Yogyakarta:

Kanisius 1990, hlm.57

${ }^{15}$ Joann Wolski Conn, Women's Spirituality : Restriction and Reconstruction, Paulist Press New York Mawah, h. 9-10

${ }^{16}$ Susan Baker and Robin Morrison, Environmental Spirituality: Grounding Our Response To Climate Change, dalam : European Journal of Science and Theology, UK : June 2008, Vol.4, No.2, p. 36.

${ }^{17}$ Susan Baker and Robin Morrison, Environmental Spirituality: Grounding Our Response, ... p. 41.

${ }^{18}$ Susan Baker and Robin Morrison, Environmental Spirituality: Grounding ,... p. 41-50.

19 Berry, Thomas. "An Ecologically Sensitive Spirituality." In Dreyer, Elizabeth and Mark S. Burrows (eds.). Minding the Spirit: The Study of Christian Spirituality. Baltimore: John Hopkins University Press, 2005, p. 245

${ }^{20}$ Paul Rabinow and William M. Sulivan [ed.], Interpretive Social Sience, A Reader, California: University of California Press, 1979, p. 148.

${ }^{21}$ J.B. Banawiratma, Kemiskinan dan Pembebasan, Yogyakarta: Kanisius, 1990, p. 123-124.

${ }^{22}$ Istilah "komoditas konsumtif” dan "komoditas profit" ini dipilih Penulis dengan menyesuaikan maknanya menurut arti dalam kamus: komoditas, yakni: bahan mentah atau barang dagangan; konsumtif (bentuk kata sifat dari konsumsi), yakni: pemakaian barang yang langsung memenuhi kebutuhan hidup; profit, yakni: keuntungan. Ini berdasarkan maknanya dalam: Kamus Besar Bahasa Indonesia Luar Jaringan, KBBI Offline v. 1.4, diunduh melalui http://ebsoft.web.id. Sehingga, frase-frase ini dimaksudkan Penulis untuk menunjuk pada barang/bahan yang dipakai untuk memenuhi kebutuhan hidup, sekaligus diperdagangkan untuk mencari keuntungan atau ditukarkan untuk menghasilkan barang yang lain.

${ }^{23}$ Lih. Philip Van Akkeren, Dewi Sri dan Kristus; Sebuah Kajian Tentang Gereja Pribumi di jawa Timur, Jakarta, BPK Gunung Mulia, 1994, p.124. Doa kepada Dewi Sri-Sadana dalam bahasa 
Jawa, terjemahannya seperti ini: Ya Bapaku yang di Surga, yang penuh dengan Kuasa, yang berkuasa menciptakan langit dan bumi. Karuniakanlah kami kemampuan untuk bercocok tanam semoga awal dari aktifitas pengolahan lahan ini membuat tanah menjadi gembur, semoga mata bajakku bisa melekat dengan kokoh, semoga Tua Air selalu mengawasi parit-parit irigasi. Semoga gemertak cemeti dapat mengarahkan sang lembu semoga garu dapat meratakan bidang tanahku, yang menjadi kesukaan Ibu Sri Sadena, sebagaimana ia tampil dalam wujud padi. Kiranya hal itu dikaruniakan Allah yang Esa dan Yesus Kristus adalah Roh Allah.

${ }^{24}$ Doa Kepada Gunung Semeru: oh gunung Semeru, yang adalah tinggi di tanah Jawa, kidung kami persembahkan kepadaMu. Berkatilah pekerjaan tangan kami. Berkatilah bajak yang membelah bumi menjadi terbuka, serta yang menjadikan bumi layak bagi bibit. Berkatilah bajak yang memotong galur, berkati tangkai, lecutan pecut kepada ternak, serta aliran air yang memberi hiduop. Galur yang baru dipotong bersinar bak minyak yang harum semerbak. Berkatilah garu yang melembutkan tanah sebagaimana yang digemari Dewi Sri, ia yang adalah dewi opadi, yang mengaruniai kelimoahan kepada kami. Dan di atas semua itu, kami berdoa untuk berkat-berkat serta kekuatan dari Yesus, yang memiliki kekuatan terbesar. (lih.C.W.Nortier,Tumbuh Dewasa Bertanggungjawab, Jakarta, BPK Gunung Mulia, 1981, p.910 .

${ }^{25}$ Lih: Budi Cahyono, Coenraad Laurens Coolen : Hidup dan Karyanya, 2013 (tidak diterbitkan), dan Budi Cahyono, Fransiskus Assisi : Hidup dan Karyanya, 2013 (tidak diterbitkan).

${ }^{26}$ Eksploitasi yang dimaksudkan di sini bukan hanya menunjuk pada makna sekedar memakai, memanfaatkan, atau mengusahakan, namun lebih kepada maknanya sebagai bentuk "pemerasan". Ini berdasarkan arti kata menurut: Cambridge Advanced Learner's Dictionary, Third Edition, Cambridge: Cambridge University Press, 2008, entry: exploit (use unfairly), juga dalam: Kamus Besar Bahasa Indonesia Luar Jaringan, KBBI Offline v. 1.4, diunduh melalui http://ebsoft.web.id.

\section{DAFTAR PUSTAKA}

Banawiratma, JW; 1990. Kemiskinan dan Pembebasan, Yogyakarta: Kanisius,

J.B.Banawiratma (eds.,) 1990. Spiritualitas Transformatif Suatu Pergumulan Ekumenis, Yogyakarta: Kanisius,

Berry, Thomas; “An Ecologically Sensitive Spirituality.” In Dreyer, Elizabeth and Mark Burrows S.(eds.). Minding the Spirit: The Study of Christian Spirituality. Baltimore: John Hopkins University Press, 2005

Budi Cahyono, Coenraad Laurens Coolen : Hidup dan Karyanya, 2013 (tidak diterbitkan)

Deane-Drummond, Celia; Teologi dan Ekologi. Jakarta: BPK Gunung Mulia, 2001.

Ismail, Andar (Ed.); Ajarlah Mereka Melakukan: Kumpulan Karangan Seputar Pendidikan Agama Kristen. Jakarta: BPK Gunung Mulia, 1998. 
Joann Wolski Conn, 2002, Women's Spirituality : Restriction and Reconstruction, Paulist Press New York Mawah

Nortier, C.W; Tumbuh Dewasa Bertanggungjawab, Jakarta, BPK Gunung Mulia, 1981

Paul Rabinow and William M. Sulivan [ed.]; Interpretive Social Sience, A Reader, California: University of California Press, 1979

Philip Van Akkeren; Dewi Sri dan Kristus; Sebuah Kajian Tentang Gereja Pribumi di jawa Timur, Jakarta, BPK Gunung Mulia, 1994

R.P. Borrong; "Etika Bumi Baru”, BPK Gunung Mulia Jakarta, 2000,

Susan Baker and Robin Morrison; Environmental Spirituality: Grounding Our Response To Climate Change, dalam European Journal of Science and Theology, UK : June 2008, Vol.4, No.2, p. 36.

Tim Penyusun Buku dan Redaksi BPK Gunung Mulia, Memperlengkapi bagi Pelayanan dan Pertumbuhan. Jakarta: BPK Gunung Mulia, 2002. 